\title{
Depression is the strongest predictor of long-term outcome in patients with chronic nonischemic heart failure
}

\author{
Bożena Szyguła-Jurkiewicz ${ }^{1}$, Michał Zakliczyński², Michał Ploch ${ }^{3}$, Mateusz Mościński ${ }^{3}$, Robert Partyka ${ }^{4}$, \\ Romuald Wojnicz ${ }^{3}$, Marian Zembala², Lech Poloński ${ }^{1}$
}

$3^{1}{ }^{\text {rd }}$ Chair and Clinical Department of Cardiology, Medical University of Silesia, Silesian Center for Heart Diseases, Zabrze, Poland ${ }^{2}$ Chair and Clinical Department of Cardiac Surgery and Transplantation, Medical University of Silesia, Silesian Center for Heart Diseases, Zabrze, Poland ${ }^{3}$ Silesian Center for Heart Diseases, Zabrze, Poland

${ }^{4}$ Department of Anesthesiology, Intensive Care and Emergency Medicine, Medical University of Silesia, Katowice, Poland

Kardiochirurgia i Torakochirurgia Polska 2014; 11 (1): 102-108

\begin{abstract}
Introduction: Despite advances in medicine, chronic heart failure (CHF) still remains a significant clinical problem associated with poor outcome.

Aim of the study: To determine risk factors for major adverse cardiac events (MACE) in three-year follow-up in patients with CHF of nonischemic etiology.

Material and methods: The prospective study included consecutive hospitalized patients with stable CHF (LVEDD > $57 \mathrm{~mm}$; LVEF < 40\%) and symptom duration > 6 months. Study exclusion criteria were: serious neurological and/or psychiatric diseases, stenoses in epicardial coronary arteries in coronarography, active myocarditis confirmed by myocardial biopsy, diseases of the respiratory system with pulmonary hypertension, presence of heart defects, neoplastic or connective tissue disease, documented infectious diseases at least three months before inclusion in the study, diabetes, liver cirrhosis, chronic kidney disease (eGFR $<30 \mathrm{ml} / \mathrm{min} / 1.73 \mathrm{~m}^{2}$ ), alcoholism, planned heart transplantation. Depression severity was assessed with the Beck and the Hamilton Scales. Depression was diagnosed based on the ICD-10 criteria. Clinical follow-up began on admission and lasted three years.

Results: The analysis encompassed 199 patients aged 49 (4154), who met the inclusion/exclusion criteria. Depression was diagnosed in $30 \%$ of the patients. Independent factors increasing the risk of MACE (death, transplantation, ventricular assist device, hospitalization) were: depression (HR: 2.26; $p<0.001$ ), E/A index (HR: 1.31; $p<0.01)$, right ventricular dimension (HR: 1.06; $p<0.01$ ), hsCRP level (HR: 1.06; $p<0.01$ ) and alkaline phosphatase activity in blood serum (HR: 1.01; $p<0.05$ ).

Conclusions: Factors affecting 3-year outcome are: depression, right ventricular dimension, the E/A index, alkaline phospha-
\end{abstract}

\section{Streszczenie}

Wstęp: Pomimo postępu, jaki dokonał się w medycynie, przewlekła skurczowa niewydolność serca (CHF) nadal stanowi istotny problem kliniczny związany z niekorzystnym rokowaniem.

Celem pracy było określenie czynników ryzyka wystąpienia niekorzystnych zdarzeń sercowych (MACE) w okresie 3 lat obserwacji u chorych z CHF o etiologii nieniedokrwiennej.

Materiat i metody: Prospektywną obserwacją objęto kolejnych hospitalizowanych chorych ze stabilną CHF (LVEDD $>57 \mathrm{~mm}$ i LVEF < 40\%) z czasem trwania objawów powyżej 6 miesięcy. Kryteria wyłączenia z badania obejmowały: poważne schorzenia neurologiczne i/lub psychiatryczne, zwężenia w nasierdziowych tętnicach wieńcowych w koronarografii (> 30\% światła naczynia), aktywne zapalenie mięśnia sercowego w biopsji endomiokardialnej, choroby układu oddechowego z nadciśnieniem płucnym, obecność istotnej wady serca, chorobę nowotworową lub chorobę tkanki łącznej, udokumentowane choroby infekcyjne w okresie przynajmniej 3 miesięcy przed włączeniem do badania, cukrzycę, marskość wątroby, przewlekłą chorobę nerek (eGFR $<30 \mathrm{ml} / \mathrm{min} / 1,73 \mathrm{~m}^{2}$ ), alkoholizm, planowaną transplantację serca. Do oceny nasilenia objawów depresji zastosowano skalę Becka oraz Hamiltona. Depresję rozpoznawano na podstawie kryteriów ICD-10. Obserwacja kliniczna została rozpoczęta przy przyjęciu do szpitala i trwała 3 lata.

Wyniki: Analizie poddano 199 chorych w wieku 49 (41-54) lat, spełniających kryteria włączenia i wyłączenia. Depresję stwierdzono u 30\% chorych. Niezależnymi czynnikami zwiększającymi ryzyko MACE (zgon, transplantacja, wspomaganie krążenia, hospitalizacja) były: depresja (HR: 2,26; $p<0,001)$, wskaźnik E/A (HR: 1,$31 ; p<0,01)$, wymiar prawej komory (HR: 1,06;

Address for correspondence: dr hab. med. Bożena Szyguła-Jurkiewicz, 3rd Chair and Clinical Department of Cardiology, Medical University of Silesia, Silesian Center for Heart Diseases, M. Curie-Sklodowskiej 9, 41-800 Zabrze, Poland, phone 004860410299, e-mail: centrala4@wp.pl 
tase activity and the level of high-sensitivity C-reactive protein (hs-CRP).

Key words: chronic heart failure, depression, prognosis. $p<0,01)$, stężenie hsCRP (HR: 1,06; $p<0,01)$ oraz aktywność fosfatazy alkalicznej w surowicy (HR: 1,$01 ; p<0,05)$.

Wnioski: Na 3-letnie rokowanie mają wpływ następujące czynniki: depresja, wymiar prawej komory, wskaźnik E/A, aktywność fosfatazy alkalicznej oraz stężenie hsCRP w surowicy.

Słowa kluczowe: przewlekła niewydolność serca, depresja, rokowanie.

Clinical follow-up began on admission and lasted three years.

Despite the considerable advances in pharmacological and interventional treatment, chronic heart failure (CHF) still remains a significant clinical problem associated with high mortality and frequent hospitalization. Depression is a serious and modifiable concomitant of CHF and it is one of the main causes of cognitive dysfunctions and patient noncompliance [1-3]. It can occur at any stage of $\mathrm{CHF}$, as a reaction to: diagnosis, imposed change of lifestyle, sudden exacerbation of symptoms or poor prognosis. Moreover, there is evidence of pathophysiological pathways common to both diseases [4]. This suggests that depression may accelerate the onset and progression of CHF, whilst CHF may cause the manifestation or exacerbation of depressive disorders. Although the presence of depressive disorders affects the course of the disease, it is frequently ignored.

The aim of the work was to determine the risk factors for major adverse cardiac events (MACE) in three-year follow-up in patients with chronic systolic heart failure. The statistical analyses take into consideration the presence of depression.

\section{Material and methods}

The prospective study included consecutive hospitalized patients with stable CHF (NYHA class II and III) with no concomitant coronary disease. For at least three months before hospitalization, all of them had been receiving: maximum tolerated doses of angiotensin-converting enzyme inhibitor (or angiotensin II receptor antagonist) and $\beta$-receptor antagonist (slow-release metoprolol or carvedilol preparations), spironolactone and furosemide. The study protocol was approved by the local Bioethics Committee.

Study inclusion criteria were: stable systolic CHF (LVEDD $>57 \mathrm{~mm}$ and LVEF < 40\%) lasting at least 6 months and optimal pharmacological treatment. Study exclusion criteria were: serious neurological and/or psychiatric diseases (especially dementia or schizophrenia), stenoses in epicardial coronary arteries (> 30\% vessel lumen) shown by coronarography, active myocarditis confirmed by myocardial biopsy (Dallas classification), diseases of the respiratory system with pulmonary hypertension, presence of acquired or congenital heart defects, clinically confirmed neoplastic or connective tissue disease, documented infectious diseases at least three months before inclusion in the study, diabetes, liver cirrhosis, chronic kidney disease, alcoholism, planned heart transplantation, and lack of the patient's written consent for inclusion in the study.

\section{Methods}

A detailed history was taken from each patient, followed by a physical examination. Laboratory tests were carried out with the Cobas Integra apparatus (Roche), and the SF-3000 (SYSMEX) or ADVIA 2120 (Siemens) analyzer. Additionally, echocardiography (VIVID-5 Vingmed, GE), resting electrocardiography, the six-minute walk test, coronarography, endomyocardial biopsy and invasive measurement of right heart pressure were performed. The severity of depressive disorders was assessed with a structured clinical history, the Beck Depression Inventory [5] and the 17-item Hamilton Rating Scale [6]. Patients with signs of depressive syndrome underwent further diagnosis by a psychiatrist with a view to diagnosing the presence of depression based on the ICD-10 criteria [7]. Data concerning long-term followup were obtained from follow-up visits, surveys completed by the patients and via telephone contact with the patients or their families. The incidence of MACE was assessed (death from any cause, re-hospitalization due to CHF exacerbation, emergency heart transplantation, ventricular assist device).

\section{Statistical analysis}

Data with normal distribution are presented as mean \pm SD with $95 \%$ confidence interval $(\mathrm{Cl})$. Data with non-normal distribution and ordinal data are presented as medians with interquartile range. Qualitative data are presented as percentages.

To compare data between two different groups of patients the following were used:

- Student's t-test was used for data with normal or normalized distribution for independent data; the homogeneity of variances was assessed with Levene's test,

- the Mann-Whitney $U$ test was used for the remaining data.

The normality of distribution of the obtained results was assessed with the Shapiro-Wilk test. To compare dichotomous variables, the $\chi^{2}$ test or its appropriate modifications were used. The effect of the studied variables on the incidence of the composite endpoint in long-term follow-up was assessed with a Cox proportional hazards model. Variables that were statistically significant $(p<0.05)$ in the single factor analysis were included in the multiple factor analysis of Cox proportional hazard with backward elimination. The results are presented as hazard ratio (HR) with $95 \% \mathrm{Cl}$, Wald statistic and significance level. 
Tab. I. Basic patient characteristics

\begin{tabular}{lc} 
Parameter & Total $(n=199)$ \\
Age [years] & $49.0 / 13.0$ \\
\hline Men [\%] & $167(83.9 \%)$ \\
\hline CHF duration [months] & $12.4 / 31.9$ \\
\hline NYHA class II & $161(80.9 \%)$ \\
\hline NYHA class III & $36(18.1 \%)$ \\
\hline Six-minute walk test [m] & $371.3 \pm 69.2$ \\
\hline Arterial hypertension & $132(66.3 \%)$ \\
\hline LVEF [\%] & $29.0 / 10.0$ \\
\hline FS [\%] & $21.4 / 9.2$ \\
\hline
\end{tabular}

The results are presented as mean $\pm S D$ or median and inter-quartile range.

CHF - chronic heart failure, eGFR - estimated glomerular filtration rate, FS - fractional shortening, HR - heart rate, LVEF - left ventricular ejection fraction,

NT-proBNP - N-terminal prohormone brain natriuretic peptide, NYHA - New York Heart Association, PAP - pulmonary artery pressure, RAP - right atrial pressure

The cumulative survival curves were plotted with the Kaplan-Meier method. The log rank test was used to compare two survival curves.

Variables with significance level $p<0.05$ were considered statistically significant. All calculations were made with Statistica 9.0, version PL, MS Office Excel and R software environment.

\section{Results}

Between 2006 and 2008, 249 patients with chronic systolic CHF without coronary disease were hospitalized at the Clinical Department of Cardiology. For at least three months before hospital admission, the patients had been receiving optimal pharmacotherapy (angiotensin-converting enzyme inhibitors, $\beta$-blockers, furosemide, spironolactone).

Based on the performed diagnostics, the final study included 199 patients who met the inclusion criteria. Of the patients who were not qualified for the study, 10 had aortic stenosis, 4 suffered from alcoholism, 6 neoplastic disease, 11 chronic obturative pulmonary disease with pulmonary

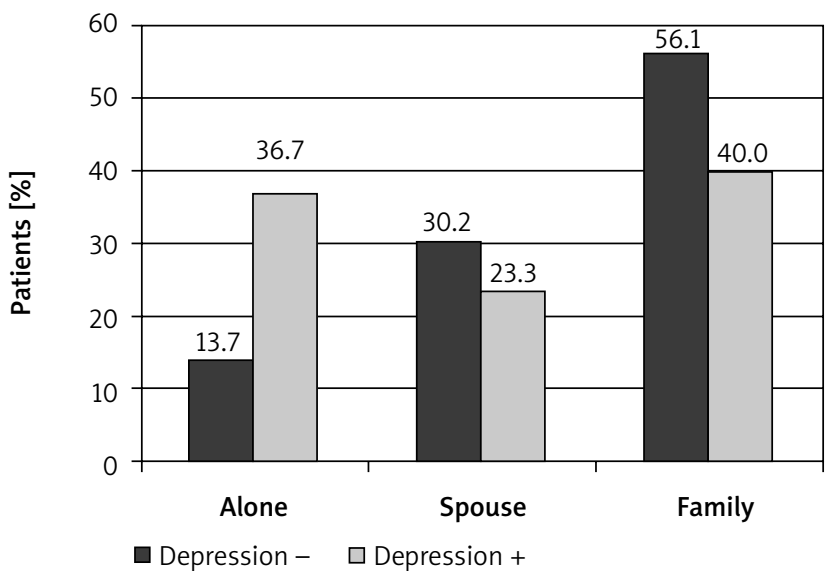

Fig. 1. The effect of living with family on the incidence of depression in the studied population

\begin{tabular}{lc} 
Parameter & Total $(n=199)$ \\
Persistent atrial fibrillation & $28(14.1 \%)$ \\
\hline HR on admission $[1 / \mathrm{min}]$ & $80 / 27$ \\
\hline PAP mean $[\mathrm{mm} \mathrm{Hg}]$ & $22.3 \pm 9.1$ \\
\hline RAP mean $[\mathrm{mm} \mathrm{Hg}]$ & $6.0 / 5.0$ \\
\hline NT-pro BNP $[\mathrm{pg} / \mathrm{ml}]$ & $844.2 / 2039$ \\
\hline eGFR $<90\left[\mathrm{ml} / \mathrm{min} / 1.73 \mathrm{~m}^{2}\right]$ & $110(55.3 \%)$ \\
\hline Depression $(\mathrm{ICD}-10)$ & $60(30.1 \%)$ \\
\hline a) single depressive episode & $50(25.1 \%)$ \\
\hline b) recurrent depressive episodes & $10(5.0 \%)$ \\
\hline
\end{tabular}

hypertension, 9 diabetes mellitus, and 10 active myocarditis according to the Dallas classification.

The basic patient characteristics are presented in Table I. Depression on admission was diagnosed in 60 (30\%) patients and occurred significantly more frequently in patients who lived alone than in patients who lived with their spouse and/or family (Fig. 1). Living alone was associated with an increased risk of depression $[R R=1.36(95 \% \mathrm{Cl}$ : $1.51-1.67) ; p<0.001]$. Only 12 (20\%) patients with a diagnosis of depression were complying with depression therapy: 10 (16.6\%) with a recurrent depressive episode and 2 (3.4\%) with the first depressive episode. All of them were receiving the selective serotonin reuptake inhibitor sertraline.

Patients with MACE had significantly longer duration of CHF, higher concentration of hs-CRP, D-dimers, NT-proBNP, and bilirubin, higher activity of alkaline phosphatase and higher mean right atrial pressure (Table II). Moreover, those patients had higher values of almost all echocardiographic parameters, except ejection fraction and LVEDV, and lower values of deceleration time (Table III).

In the three-year follow-up period, major adverse cardiac events (MACE) occurred in $83(41.7 \%)$ patients. In five (2.5\%) patients, an ICD device was implanted. The KaplanMeier curves in Figure 2 present the cumulative MACE-free survival in the group with and without depression.

Hospitalization, MACE episodes and death occurred significantly more frequently in the group with depression than in the group without depression: $43.8 \%$ vs. $25.9 \%$ $(p<0.05 ; \mathrm{RR}=1.31 ; 95 \% \mathrm{Cl}: 1.03-1.6), 68.3 \%$ vs. $30.2 \%$ $(p<0.001 ; \mathrm{RR}=2.20 ; 95 \% \mathrm{Cl}: 1.49-3.25)$, and $71.7 \%$ vs. $28.1 \%$ ( $p<0.001, \mathrm{RR}=2.54 ; 95 \% \mathrm{Cl}: 1.67-3.84$ ), respectively.

MACE risk factors in the multivariate, stepwise backward, Cox proportional hazard analysis are presented in Table IV.

\section{Discussion}

In the analyzed group of patients, depression was diagnosed in $30 \%$ of individuals and had the strongest prognostic value during three-year follow-up. In medical da- 
tabases, there are few reports analyzing the impact of depression in this group of patients $[8,9]$. Most publications concern the population of patients with ischemic or etiologically heterogeneous CHF $[10,11]$.

The 2006 meta-analysis by Rutledge et al. showed that the prevalence of depression in patients with $\mathrm{CHF}$ was from $9 \%$ to $60 \%$ [12]. Furthermore, the meta-analysis demonstrated that depression increases the risk of adverse cardiac events 2 -fold. This is in consonance with our results.

Septoe et al. analyzed a group of patients with dilated cardiomyopathy [8]. The incidence of depression in that study was $22 \%$ and was lower than in our study, although the results are not easily comparable as the tool used by Septoe et al. to diagnose depression was the Hospital Anxiety and Depression Scale (HADS). Furthermore, the analysis was retrospective and had a low response rate (60\%). Faris et al. analyzed retrospectively almost 400 patients with non-ischemic CHF [9]. In that study, depression was diagnosed based on the ICD-10 classification and was present in $83(21 \%)$ patients, most of whom (60\%) were receiving antidepressants. Depression significantly increased the risk of death and hospitalization in five-year follow-up. Interestingly, the prognosis in patients receiving antidepressants was not significantly different from that in patients with untreated depression. This may have been caused by the fact that a large percentage of the patients were receiving cardiotoxic tricyclic antidepressants (60\%), whilst a small percentage of patients were treated with $\beta$-blockers (8\%), which inhibit the activation of the sympathetic nervous system occurring in depression and CHF.

Our results are in consonance with the results of the $\mathrm{COACH}$ study, encompassing over 900 patients with ischemic and non-ischemic CHF followed up for 18 months. Although in that study depression was diagnosed with the CES-D scale, the follow-up was shorter, and $49 \%$ of the ana-

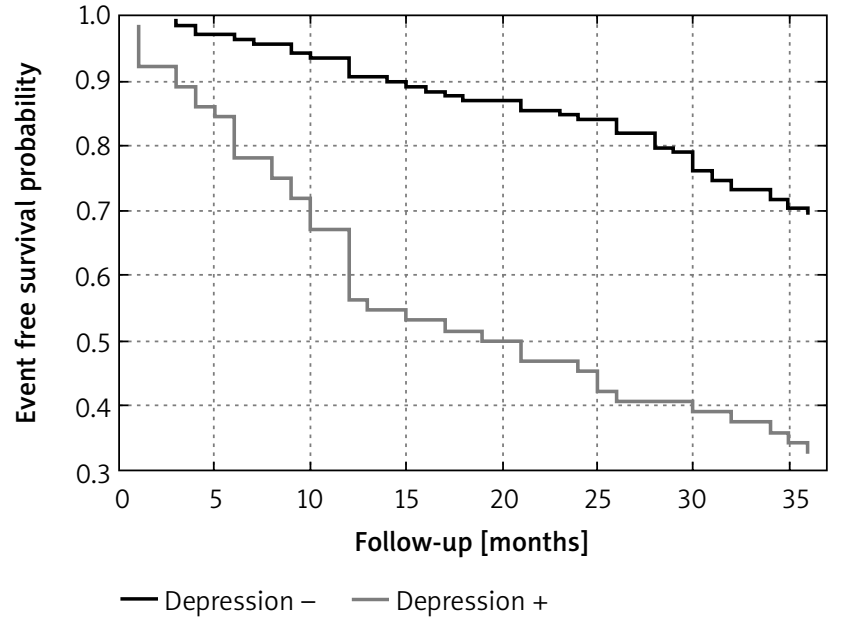

Fig. 2. Kaplan-Meier curve showing cumulative MACE-free survival in the group with and without depression; $p_{\text {log-rank }}<0.001$

lyzed patients were in NYHA class III/IV, still, as in our study, depression proved to be an adverse prognostic factor. The incidence of depression in the COACH study patients was $39 \%$, yet anti-depression treatment was followed by $11 \%$ only. The high incidence of depression in the $\mathrm{COACH}$ study may have been associated both with the high percentage of patients with advanced CHF, and with the fact that depression was diagnosed based on a questionnaire, and not on diagnostic criteria [13]. Van den Broek et al. analyzed the data of 208 patients with CHF of various etiology (62\% ischemic). The incidence of depression in the analyzed group was $36.1 \%$. The presence of depression increased the risk of death from cardiovascular causes 2-fold in 11-year follow-up [14]. The retrospective analysis of 5,719 patients conducted by Albert et al. as part of the OPTIMIZE-HF trial revealed the presence of depression in only $13.6 \%$ of pa-

Tab. II. Patient characteristics in group without MACE (A) and with MACE (B)

\begin{tabular}{|c|c|c|c|}
\hline & Group A, $n=116$ & Group B, $n=83$ & \\
\hline Age [years] & $50.0(12.0)$ & $47.0(14.0)$ & NS \\
\hline Men [\%] & $100(86.2 \%)$ & $67(80.7 \%)$ & NS \\
\hline CHF duration [month] & $12.0(30.0)$ & $24.0(53.0)$ & $<0.05$ \\
\hline Depression & $19(16.4 \%)$ & $41(49.4 \%)$ & $<0.001$ \\
\hline Glucose > $5.8[\mathrm{mmol} / \mathrm{l}]$ & $32(27.6 \%)$ & $32(38.6 \%)$ & NS \\
\hline $\mathrm{eGFR}<90\left[\mathrm{ml} / \mathrm{min} / 1.73 \mathrm{~m}^{2}\right]$ & 59 (50.9\%) & $51(61.4 \%)$ & NS \\
\hline hs-CRP [mg/l] & $1.71(2.22)$ & $2.74(4.43)$ & $<0.05$ \\
\hline D-dimers $[\mu \mathrm{g} / \mathrm{ml}]$ & $0.220(0.100)$ & $0.250(0.380)$ & $<0.01$ \\
\hline NT-pro BNP [pg/ml] & $620.4(922.0)$ & $1701.0(3456.0)$ & $<0.001$ \\
\hline Alkaline phosphatase [U/l] & $63.0(20.0)$ & $75.0(34.0)$ & $<0.01$ \\
\hline AspAT [U/l] & $24.0(9.0)$ & $25.0(13.0)$ & NS \\
\hline AlAT [U/I] & $29.5(19.0)$ & $26.0(19.0)$ & NS \\
\hline Bilirubin [mmol/l] & $18.7 \pm 9.6$ & $22.6 \pm 12.3$ & $<0.05$ \\
\hline
\end{tabular}


Tab. III. Patients' echocardiography characteristics in group without MACE (A) and with MACE (B)

\begin{tabular}{lccc} 
& Group A, $n=116$ & Group B, $n=83$ & \\
LVEF [\%] & $30.0(10.0)$ & $20.0(10.0)$ & NS \\
\hline LVEDV [ml] & $203.1 \pm 71.8$ & $222.9 \pm 81.2$ & NS \\
\hline LVESV [ml] & $141.1 \pm 59.6$ & $160.7 \pm 70.3$ & $<0.05$ \\
\hline LA [mm] & $42.2 \pm 5.1$ & $43.9 \pm 6.1$ & $<0.05$ \\
\hline RVEDd [mm] & $26.0 \pm 6.0$ & $29.8 \pm 7.5$ & $<0.001$ \\
\hline E/A & $1.40(1.25)$ & $1.75(2.40)$ & $<0.001$ \\
\hline DT [ms] & $193.0(131.0)$ & $165.0(122.0)$ & $<0.001$
\end{tabular}

DT - deceleration time, LA - left atrium, LVEDV - left ventricular end diastolic volume, LVEF - left ventricular ejection fraction, LVESV - left ventricular end systolic volume, RVEDd - right ventricular end diastolic diameter

tients. In that trial, depression was an independent risk factor for prolonged hospitalization and death from all causes within three months after discharge [15].

One of the prognostic factors in the analyzed population was high-sensitivity CRP (hs-CRP). The prognostic value of hs-CRP in CHF has been confirmed by many authors $[16,17]$. Some authors, however, observed that the cutoff points for hs-CRP, above which there was an increased risk of adverse cardiac events, were generally within normal ranges for the healthy population [18-20]. In healthy individuals, the hs-CRP concentration was $<5 \mathrm{mg} / \mathrm{l}$, whilst the cutoff point for high risk of adverse cardiac events was $>3.0 \mathrm{mg} / \mathrm{l}$ [16]. Importantly, an increased CRP concentration is a non-specific response to cellular damage and inflammatory processes; hence its elevated level may result from an ongoing inflammatory process unconnected with the cardiovascular system [21]. However, inflammatory processes, even of low intensification and unconnected with the cardiovascular system, may have an impact on $\mathrm{CHF}$ exacerbation. The analyses of large epidemiological studies show that hs-CRP concentration correlates with the majority of classic risk factors in cardiovascular diseases. Still, an independent impact of hsCRP on prognosis in selected groups of CHF patients cannot be excluded [22].

The right ventricular size assessed echocardiographically was another prognostic factor in our study. Disorders of the right ventricular function are well-known prognostic factors of poorer outcome in patients with advanced CHF [23]. However, there are few publications analyzing this relationship in patients with moderate CHF. Larose et al. and Juiliere et al. showed that impaired right ventricular function was a prognostic index both in patients with ischemic and nonischemic CHF [24, 25]. De Groote et al. conducted a study including 205 patients with CHF in NYHA class II and III and LVEF 29\% (study inclusion criteria similar to ours). In most patients (59\%), ischemic CHF was excluded by coronarography. The authors found that in 755 days of follow-up, RVEF was an adverse prognostic factor in the analyzed group of patients [26]. The prognostic role of right ventricular dysfunction in patients with CHF was also confirmed by Spiranova et al. based on their results in patients with NYHA class II-IV. The studied group was not homogeneous with regard to CHF etiology (55\% ischemic heart disease, $45 \%$ idiopathic dilated cardiomyopathy). The study showed that the more impaired the right ventricular systolic function is, the bigger is its size and the higher are the right heart pressures [27].

The next prognostic factors in our study were Doppler mitral flow parameters, which reflect the left ventricular filling dynamics connected with its diastolic function. The values of these parameters in patients with chronic systolic CHF provide important information as to the type of hemodynamic disorders. In the analyzed group of patients, the E/A index was an independent prognostic factor. A value of this index above 1.4 was associated with an increased risk of adverse cardiac events. Similar results were obtained by Somaratne, who in his meta-analysis of 887 patients found a significant effect of right ventricular diastolic dysfunction on the occurrence of adverse cardiac events in 15 months of follow-up [28]. Based on the type of mitral flow, groups of $\mathrm{CHF}$ patients with better and poorer long-term prognosis can be selected. This is important inasmuch as intensive pharmacotherapy may restore correct mitral inflow, thereby improving the long-term prognosis.

Yet another factor increasing the risk of MACE in the analyzed group of patients was alkaline phosphatase activity. Elevated cholestasis indexes in patients with heart failure were also observed by other authors [29-32].

The prognostic value of bilirubin in patients with stable systolic CHF due to hypertension was confirmed by Szymik et al. [30]. Allen et al. in a large prospective analysis of 2679 patients of the CHARM program found a significant relationship between the concentration of bilirubin and the incidence of MACE in 38-month follow-up [30]. Based on a 36-month prospective follow-up of 1032 patients, Poelzl

Tab. IV. MACE risk factors. Results of multivariate, stepwise backward, Cox proportional hazard analysis

\begin{tabular}{|c|c|c|c|c|}
\hline Parameter & HR & $\pm 95 \% \mathrm{Cl}$ & Wald statistic & $P$ \\
\hline Depression & 2.2641 & $1.4266-3.5932$ & 12.02 & $<0.001$ \\
\hline $\mathrm{E} / \mathrm{A}$ & 1.3060 & $1.0900-1.5646$ & 8.38 & $<0.01$ \\
\hline RVEDd [mm] & 1.0594 & 1.0177-1.1029 & 7.93 & $<0.01$ \\
\hline hs-CRP $[\mathrm{mg} / \mathrm{dl}]$ & 1.0604 & $1.0120-1.0820$ & 7.06 & $<0.01$ \\
\hline Alkaline phosphatase [U/I] & 1.0114 & $1.0026-1.0203$ & 6.46 & $<0.05$ \\
\hline
\end{tabular}


et al. concluded that alkaline phosphatase and $\gamma$-glutamyl transpeptidase (GGTP) significantly increased the risk of adverse cardiac events [31]. No such correlation was observed for aminotransferase. The authors demonstrated that in stable CHF, the cholestatic component of impaired liver function is predominant, whilst in acute heart failure, mainly ischemic damage to hepatocytes and increase in transaminase occur [31].

\section{Strengths and limitations of the study}

The strengths of the study are its prospective character, a relatively large group of patients with $\mathrm{CHF}$ of homogeneous etiology, and long follow-up. Unlike many other studies discussing depression in CHF, in this study depression was diagnosed by a psychiatrist based on the ICD-10 criteria; this should become standard management in this group of patients [33]. The value of the study would be higher if patients with depression had been randomized to groups treated with pharmacotherapy and psychotherapy. Nevertheless, this type of study would have been impossible to conduct due to the small percentage of patients complying with depression therapy (20\% of patients with diagnosis of depression). For the same reason, the effect of pharmacotherapy of depression on outcome was not considered. As a result, the analyzed group was not homogeneous with regard to depression therapy. However, the exclusion of noncompliant patients from further follow-up would have made it impossible to interpret the results correctly.

\section{Conclusions}

1. Depression, present in $30 \%$ of the analyzed patients with $\mathrm{CHF}$ of nonischemic etiology, is an independent risk factor for adverse cardiac events and increases the risk of death, transplantation or hospitalization due to CHF exacerbation in 3-year follow-up.

2. Other clinical parameters affecting long-term follow-up are: increased right ventricular dimension, the E/A index, alkaline phosphatase activity and the level of high-sensitivity C-reactive protein (hSCRP).

\section{References}

1. Szyguła-Jurkiewicz B, Pudlo R, Samborski K, Muzyk P. Depression in chronic heart failure. Kardiochir Torakochir Pol 2012; 9: 502-506.

2. Michalak A, Szyguła-Jurkiewicz B, Mościński M, Muzyk P, Samborski K, Kłaczek B, Knapik P, Zembala M, Poloński L. Neuropsychological changes after off-pump and on-pump coronary artery bypass surgery. Kardiochir Torakochir Pol 2013; 10: 334-340.

3. Cameron J, Worrall-Carter L, Page K, Riegel B, Lo SK, Stewart S. Does cognitive impairment predict poor self-care in patients with heart failure? Eur J Heart Fail 2010; 12: 508-515.

4. Parissis JT, Fountoulaki K, Paraskevaidis J, Kremastinos D. Depression in chronic heart failure: novel pathophysiological mechanisms and therapeutic approaches. Expert Opin Investig Drugs 2005; 14: 567-577.

5. Beck AT, Ward CH, Mendelson M, Mock J, Erbaugh J. An inventory for measuring depression. Arch Gen Psychiatry 1961; 4: 561-571.

6. Hamilton M. A rating scale for depression. J Neurol Neurosurg Psychiatry 1960; 23: 56-62.

7. The ICD-10 Classification of Mental and Behavoral Disorders. Diagnostic criteria for research. World Health Organization, Geneva 2003; pp. 27-172.
8. Steptoe A, Mohabir A, Mahon NG, McKenna WJ. Health related quality of life and psychological wellbeing in patients with dilated cardiomyopathy. Heart 2000; 83: 645-650.

9. Faris R, Purcell H, Henein MY, Coats AJ. Clinical depression is common and significantly associated with reduced survival in patients with non-ischemic heart failure. Eur J Heart Fail 2002; 4: 541-551.

10. Xiong GL, Fiuzat M, Kuchibhatla M, Krishnan R, O'Connor CM, Jiang W; SADHART-CHF Investigators. Health status and depression remission in patients with chronic heart failure: patient-reported outcomes from the SADHART-CHF trial. Circ Heart Fail 2012; 5: 688-692.

11. Smith OR, Kupper N, Schiffer AA, Denollet J. Somatic depression predicts mortality in chronic heart failure: can this be explained by covarying symptoms of fatigue? Psychosom Med 2012; 74: 459-463.

12. Rutledge T, Reis VA, Linke SE, Greenberg BH, Mills PJ. Depression in heart failure. A meta-analytic review of prevalence, intervention effects and associations with clinical outcomes. J Am Coll Cardiol 2006; 48: 1527-1537.

13. Lesman-Leegte I, van Veldhuisen DJ, Hillege HL, Moser D, Sanderman R, Jaarsma T. Depressive symptoms and outcomes in patients with heart failure: data from the COACH study. Eur J Heart Fail 2009; 11: 1202-1207.

14. Van den Broek KC, DeFilippi CR, Christenson RH, Seliger SL, Gottdiener JS, Kop WJ. Predictive value of depressive symptoms and B-type natriuretic peptide for new-onset heart failure and mortality. Am J Cardiol 2011; 107: 723-729.

15. Albert NM, Fonarow GC, Abraham WT, Gheorghiade M, Greenberg BH, Nunez E, O'Connor CM, Stough WG, Yancy CW, Young JB. Depression and clinical outcomes in heart failure: an OPTIMIZE-HF analysis. Am J Med 2009; 122: 366-373.

16. Lamblin N, Mouquet F, Hennache B, Dagorn J, Susen S, Bauters C, de Groote P. High-sensitivity $\mathrm{C}$-reactive protein: potential adjunct for risk stratification in patients with stable congestive heart failure. Eur Heart J 2005; 26: 2245 2250.

17. Alonso-Martínez JL, Llorente-Diez B, Echegaray-Agara M, Olaz-Preciado F, Urbieta-Echezarreta M, González-Arencibia C. C-reactive protein as a predictor of improvement and readmission in heart failure. Eur J Heart Fail 2002; 4: 331-336.

18. Pepys MB. CRP or not CRP? That is the question. Arterioscler Thromb Vasc Biol 2005; 25: 1091-1094.

19. Lowe GD. Circulating inflammatory markers and risk of cardiovascular and non-cardiovascular disease. J Thromb Haemost 2005; 3: 1618-1627.

20. Danesh J, Wheeler JG, Hirschfield GM, Eda S, Eiriksdottir G, Rumley A, Lowe GD, Pepys MB, Gudnason V. C-reactive protein and other circulating markers of inflammation in the prediction of coronary heart disease. $N$ Engl J Med 2004; 350: 1387-1397.

21. Czerniuk MR, Górska R, Filipiak KJ, Opolski G. C-reactive protein in patients with coexistent periodontal disease and acute coronary syndromes. J Clin Periodontol 2006; 33: 415-420.

22. Miller M, Zhan M, Havas S. High attributable risk of elevated C-reactive protein level to conventional coronary artery heart disease risk factors: the Third National Health and Nutrition Examination Survey. Arch Intern Med 2005; 165: 2063-2068.

23. Field ME, Solomon SE, Lewis EF, Kramer DB, Baughman KL, Stevenson LW, Tedrow UB. Right ventricular dysfunction and adverse outcome in patients with advanced heart failure. J Card Fail 2006; 12: 616-620.

24. Larose E, Ganz P, Reynolds HG, Dorbala S, Di Carli MF, Brown KA, Kwong RY. Right ventricular dysfunction assessed by cardiovascular magnetic resonance imaging predicts poor prognosis late after myocardial infarction. J Am Coll Cardiol 2007; 49: 855-862.

25. Juiliere Y, Barbier G, Feldmann L, Gretzinger A, Dauchin N, Cherrier F. Ad ditional predictive value of both left and right ventricular ejection fractions on long-term survival in idiopathic dilated cardiomyopathy. Eur Heart J 1997; 18: 276-280.

26. De Groote P, Millaire A, Foucher-Hossein C, Nugue O, Marchandise X, Ducloux $G$, Lablanche JM. Right ventricular ejection fraction is an independent predictor of survival in patients with moderate heart failure. J Am Coll Cardiol 1998; 32: 948-954.

27. Spinarova L, Meluzin J, Toman J, Hude P, Krejci J, Vitovec J. Right ventricular dysfunction in chronic heart failure patients. Eur J Heart Fail 2005; 7 : 485-489.

28. Somaratne JB, Whalley GA, Poppe KK, Gamble GD, Doughty RN. Pseudonormal mitral filling is associated with similarly poor prognosis as restrictive filling in patients with heart failure and coronary heart disease: a system- 
atic review and meta-analysis of prospective studies. J Am Soc Echocardiogr 2009; 22: 494-498.

29. Vasconcelos LA, de-Almeida EA, Bachur LF. Clinical evaluation and hepatic laboratory assessment in individuals with congestive heart failure. Arq Bras Cardiol 2007; 88: 590-595.

30. Szymik M, Szyguła-Jurkiewicz B, Partyka R, Owczarek A, Spinczyk B, Chudek J, Poloński L. Three-year survival of patients with chronic systolic heart failure due to hypertension: analysis of prognostic factors. Pol Arch Med Wewn 2012; 122: 543-550.

31. Allen LA, Felker GM, Pocock S, McMurray JJ, Pfeffer MA, Swedberg K, Wang D, Yusuf S, Michelson EL, Granger CB; for CHARM Investigators. Liver function abnormalities and outcome in patients with chronic heart failure: data from the Candesartan in Heart Failure: Assessment of Reduction in Mortality and Morbidity (CHARM) program. Eur J Heart Fail 2009; 11: 170-177.

32. Poelzl G, Ess M, Mussner-Seeber C, Pachinger O, Frick M, Ulmer H. Liver dysfunction in chronic heart failure: prevalence, characteristics and prognostic significance. Eur J Clin Invest 2011; 30: 1-11.

33. Pudlo R, Szyguła-Jurkiewicz B, Piegza M, Jaworska I, Matysiakiewicz J, Zembala M. Can a psychiatrist be helpful for a cardiologist? Kardiochir Torakochir Pol 2013; 10: 425-429. 